\title{
A REVIEW OF LEGISLATION PERTAINING TO CHILDREN, WITH PARTICULAR EMPHASIS ON PROGRAMMES OFFERED TO CHILDREN AWAITING TRIAL AT SECURE CARE CENTRES IN SOUTH AFRICA
}

\section{Annie Singh, Vanessa Singh}

\section{INTRODUCTION}

Prior to 1994, and particularly during the apartheid era, legislation and policies in South Africa did not protect children adequately. This situation was viewed as akin to "a war against children" (Skelton, 2004:9), given that "children were subjected to profound suffering" (Devenish, 1999:371). Within this context, the concept of secure care was non-existent. The position in South Africa during this period was that children who were arrested for committing crimes were detained with adults in prisons and police cells throughout the country. Under these conditions children were subjected to grave contraventions of their human rights (Skelton, 2004). There were certainly no programmes or secure care facilities to deal with such contraventions.

Since the early 1990s campaigns such as "Justice for children: No child should be Caged", the National Working Committee on "Children In Detention" and "Free a Child for Christmas" began to address the issue of the dearth of effective means of dealing with young offenders in South Africa. From the findings on the investigation of conditions in South African prisons, Sloth-Nielson and De Villiers (1998) unveiled a grim picture of conditions in South African prisons. Because of the harsh and dehumanising conditions of most of the prisons visited, overcrowding was identified as a stumbling block that did not provide a rehabilitative experience for the child. Furthermore, children suffered from the isolation of being separated from their families. It was also revealed that without a proportionate increase in prison staff, the influx of young offenders being sentenced to imprisonment meant that prisons were unable to provide stimulation to incarcerated youth by way of developmental programmes (SlothNielsen \& De Villiers, 1998). It is interesting that the need for developmental programmes was recognised quite early in the development of child justice in South Africa. Such programmes also form the basis of the discussion in this article.

According to Fine (1996:14), child-based programmes are described as multi-purpose, multi-layered, transformational, multi-focused, multi-resourced and holistic in their intention, and as having a specific intention and clear purpose from which objectives and a vision can be shaped. Programmes are viewed as a journey, with a beginning and an end, and when participating in a programme, a change of process takes place - which should bring about changes in thinking and behaviour. A similar definition of programmes is presented by the National Department Social Crime Prevention Directorate (2010:5).

The aim of the article is to review and assess legislation since the inception of the current constitutional order. The article examines the quality of programmes that are 
required to be in place for children awaiting trial at secure care centres in South Africa and determines whether they are consistent with the legislation being reviewed. A discussion on suggestions for dealing with inadequacies and discrepancies identified in this regard is also presented (see Recommendations).

\section{DEFINITION OF SECURE CARE}

The Department of Social Development (2010:3) defines secure care as "a residential facility and/or programme of intervention which ensures the appropriate physical, behavioural and emotional containment of young people who are charged with crimes and who are awaiting trial or sentenced. Such a facility provides an environment, milieu and programme conducive to the care, safety and healthy development of each young person while at the same time ensuring the protection of communities." Section 1(q) of the Children's Amendment Act 41 of 2007 (hereafter Children's Amendment Act), states that secure care means "physical containment in a safe and healthy environment" and pertains to children who display behavioural and emotional difficulties, as well as children in conflict with the law.

In a sense secure care can be viewed as a remand centre where children await trial, pending the finalisation of their cases. However, current children's legislation such as the Children's Act 38 of 2005 (hereafter the Children's Act), the Children's Amendment Act 41 of 2007, the Child Justice Act 75 of 2008 (hereafter the Child Justice Act), and the Probation Services Act 116 of 1991 (as amended) (hereafter the Probation Services Act) all focuses on the significance of programmes in this regard. This means that despite secure care being a short-term remedy to meet basic needs such as food, clothing, health care and temporary safe care whilst awaiting trial, it should also offer programmes with an emphasis on crime prevention, assessments, diversion and selfdevelopment. The implication is that a young person's stay at secure care must have a meaningful impact on them in order to constructively change their behaviour.

\section{BACKGROUND}

In South Africa prior to 1948 children who committed crimes were subjected to whipping or sent to reform schools to serve sentences (Skelton, 2004). A reform school can be described as a residential institution where children who have been sentenced by courts of law are placed (Child Justice Project, 2002). Furthermore, reform schools were described as institutions, which were residential care facilities that catered for children who were removed from their families or communities in terms of a specific court order (Child Justice Project, 2002).

During the time mentioned above there was some advocacy in South Africa for children's laws in respect of children committing crimes. These initiatives, however, disappeared during the apartheid era, when no appropriate services were offered to children in general. The services that were offered to children were racially based. This prompted the transformation of the child and youth-care system in the country after 1994 (Inter-Ministerial Committee on Young People at Risk, 1996a). A report entitled "In Whose Best Interest" was produced. This was a cabinet-endorsed investigation into the 
status of places of safety, reform schools and schools of industries in South Africa at the time. It was found, unfortunately, that children languished in state institutions. Furthermore, it was found that there was a dearth of developmental and therapeutic programmes for children who were emotionally and behaviourally troubled (InterMinisterial Committee on Young People at Risk, 1996b).

The democratisation of South Africa in 1994 resulted in legislative changes in respect of children who found themselves in conflict with the law. These included the aforementioned new laws which prescribed the manner in which child offenders were to be dealt with. The changes in legislation were necessary as children were previously dealt with in terms of the medical model and were "treated", punished or labelled for their misbehaviours and transgressions. This model was replaced by the "developmental and ecological perspective which focused on reframing problems as strengths, on competence building, and residential environments that empower children, families and communities" (Inter-Ministerial Committee on Young People at Risk, 1996a:17). This implied a paradigm shift from the retributive system with a focus on punishment, to a restorative justice approach which promoted accountability and reconciliation (Department of Social Development, undated).

Secure care is a relatively new concept in South Africa, and the term itself was coined during the transformation of the child and youth care system (Department of Social Development, 2010:3). This took place in 1995, when the Government of National Unity promulgated legislation and mandated the IMC (Inter-Ministerial Committee) to oversee the release from prisons of children awaiting trial. In South Africa the secure care model is overseen by the Department of Social Development, which is responsible for the care and protection of vulnerable groups such as children and youths. In terms of the Annual Performance Plan 2012-2013 (KwaZulu-Natal Department of Social Development, 2012:12), the model provided for the development of "a national strategy to reduce the number of youth in conflict with the law and promote youth development within the framework of the National Crime Prevention Strategy and in partnership with the National Youth Commission". This reflects the commitment by the Department to ensuring that children experience a child-orientated and child-centred environment, and not a correctional or prison-type setting. This is because the secure care model offered a more child-orientated environment, and was regarded as having a more positive impact on the child awaiting trial.

In 1995 South Africa ratified the Convention on the Rights of the Child and became a state party to the African Charter on 9 July 1996 (Viljoen, 2009). Viljoen emphasised the impact of this on the development of South African law, given that the Convention played an important role in the drafting of the South African Constitution and led to a comprehensive provision of children's rights (Viljoen, 2009:349). Article 40 of the Convention of the Rights of the Child highlighted that children accused of crimes were to be treated in a way that upheld their sense of dignity and worth. In line with this philosophy the Correctional Services Amendment Act 17 of 1994 amended Section 29 of Correctional Services Act 8 of 1959. It provided that children under the age of 18 could no longer be held in prisons and police cells while awaiting trial. The implication 
of this enactment resulted in the immediate release of the children into their parents' custody, or to state care facilities such as places of safety (Inter-Ministerial Committee on Young People at Risk, 1996a:8). Places of safety are primarily designed for the temporary care and protection of children referred through the Children's Court (InterMinisterial Committee on Young People at Risk, 1996a:8). Beukes and Gannon (1996) state that a place of safety may be used as temporary accommodation before more permanent plans for a child can be made. It is highlighted that it is seldom possible to make instant plans for the admission of children to an appropriate institution, and places of safety play an important role in caring for children while these arrangements are being made (Beukes \& Gannon, 1996:10).

In terms of the Inter-Ministerial Committee on Young People at Risk (1996a), a crisis ensued, as state-administered places of safety were not secure enough - resulting in large numbers of children absconding from them. The response by government resulted in the setting up of the IMC chaired by the Department of Social Development comprising the government departments of Justice, Safety and Security and various nongovernmental organisations (hereafter NGOs) - to address the crisis. In terms of the Interim National Protocol for the Management of Children Awaiting Trial Document, it was suggested that secure care facilities be created as an alternative to imprisonment for children awaiting trial (Child Justice Project, undated:1). It seems this was the first reference to a "secure care facility" in the South African context. It was emphasised at this stage that the secure care facility should have heightened levels of security, including features such as secured lighting and ceilings, monitors and closed-circuit television sets (CCTVs), but should not resemble a prison.

What then emerged was an inter-sectoral approach between departments and organisations, which was regarded as necessary for dealing with issues pertaining to children awaiting trial. The reason was that issues pertaining to children in general were expansive and could not be coordinated by one department alone. With respect to children awaiting trial, at least four government departments were identified - Justice, Social Development, Correctional Services, and Safety and Security - which would deal directly with matters of juvenile justice. NGOs such as the National Institute for the Rehabilitation for Criminal Offenders (NICRO), Lawyers for Human Rights, the National Association of Child Care Workers (NACCW) and the Community Law Centre also formed part of the IMC tasked to manage the process of crisis intervention, and to bring about a transformation of the child and youth care system (Inter-Ministerial Committee on Young People at Risk, 1996a:8). Other crucial government agencies regarded as part of the inter-sectoral collaboration, and which were instrumental in affecting these changes, were the departments of Health and Education.

According to the Department of Social Development (2010), in order to deliver an effective, integrated service to children and families, a shared vision and strong intersectoral collaboration and support were essential. The document cites the mission of secure care programmes as providing an enabling, caring, safe and secure environment, and services which are integrated, holistic and developmental in nature for children in conflict with the law. The Department of Social Development was to provide residential, 
therapeutic and developmental services and programmes for the children awaiting trial, while other Departments had roles identified as follows (Department of Social Development, 2010:39):

- Department of Safety and Security: The Police were to inform families of the child's arrest, and were to assist families in finding and escorting children to be hospitalised or who had to attend funerals;

- Department of Justice: Officials were to ensure that probation officers had easy access to children appearing in court, and that they would allow assessments of the children concerned;

- The National Prosecuting Authority: Involved in making decisions about prosecuting a child, and considering placement of a child in the absence of the guardian;

- Department of Education: Responsible for the provision of educational programmes at secure care centres;

- Department of Health: Officials were to undertake age estimations of children and provision of services to children who displayed psychological problems at the secure care centre;

- Department of Public Works: Responsible for the maintenance of secure care facilities.

\section{THE CONSTITUTION OF THE REPUBLIC OF SOUTH AFRICA, 1996}

In terms of Section 28(3) of the South African Constitution (1996), children are regarded as persons under the age of 18. The Bill of Rights, as outlined in Chapter Two, attributes special rights to children, given that they are considered to be vulnerable (Currie \& De Waal, 2005). Section 28(1)(g) states that arrested children awaiting trial are:

not to be detained except as a last resort, in which case, in addition to the rights a child enjoys under Sections 12 and 35, and that the child may be detained only for the shortest appropriate period of time, and has the right to be-

(i) kept separately from detained persons over the age of 18 years and

(ii) treated in a manner, and kept in conditions, that take account of the child's age.

Furthermore, in terms of Section 28(1)(h), a legal practitioner is to be assigned to the child by the state, and at state expense, in civil proceedings affecting the child. This is if substantial injustice would otherwise result.

Section $28(1)(\mathrm{g})$ provides that children are not to be detained, except as a measure of last resort, and should be kept separately from adults and treated in a manner in according to their age. This formulation was influenced by two international documents - the United Nations Standard Minimum Rules for the Administration of Juvenile Justice, and the United Nations Rules for the Protection of Juveniles and Promotion of their Liberty (Devenish, 1999:390). Similarly, Badenhorst (2012) comments that Article 37(b) of the United Nations Convention on the Rights of the Child, 1989, states that the arrest, 
detention or imprisonment of a child shall be in conformity with the law - and should be used only as a measure of last resort and for the shortest, appropriate period of time.

In line with the sentiments echoed in the Constitution were the thrust of the Child Justice Act and the Children's Act - both of which dealt specifically with the needs of children. Children's rights, child-centeredness and the best interests of children are at the heart of these pieces of legislation. While the Constitution itself does not make specific reference to programmes, it does provide that services are to be offered to children. The issues of "last resort" or "shortest possible period", as emphasised in Section 28(1)(g) in respect of children awaiting trial, confirm that the interests of children are strongly supported in the Constitution. Devenish (1999) argues that the issue of detention of children, as provided in Section $28(1)(\mathrm{g})$, is one that must be effected with circumspection, considering factors such as the age of the child, the gravity of the offence, and the interests of the community. In discussing the relevance of the Constitution and the impact it has had in influencing the types of programmes and services offered to children who are arrested, it is submitted that since the advent of the Constitution, several positive changes have been effected - which are reflected in the current legislation.

Because of the negative connotations associated with certain terms initially used in the Constitution, they were replaced with more "child-friendly" ones, as implementation of legislative mandates unfolded. In terms of current practice and trends, the word "detention" has been replaced by "child awaiting trial" or "child in conflict with the law". Furthermore, the word "detention centre", has been replaced by "secure care centres", which has in turn been changed to "child and youth care centres", as articulated in the Children's Act of 2005 (promulgated in 2008).

A more detailed examination of the relevant legislation follows below.

\section{CURRENT LEGISLATION, WITH PARTICULAR EMPHASIS ON PROGRAMMES}

\section{Probation Services Act, 116 of 1991 (as amended)}

This Act was amended (see Section 3) so as to provide for programmes or services aimed at the prevention and combating of crimes (National Department Social Crime Prevention Directorate, 2010). The focus of the amendment was also to render assistance to families of persons detained in a prison or reform school, and to give information to and provide for the treatment of offenders and other persons. The Act places the onus on the Department of Social Development to assist persons and children at risk and in conflict with the law - with programmes and relevant services (National Department Social Crime Prevention Directorate, 2010). The Act introduced key transformative practices such as assessments, the provision of Assistant Probation Officers, family finding, and home-based supervision - as an alternative to detention awaiting trial (Department of Social Development, undated). 


\section{Child Justice Act, 75 of 2008}

For most of the period 1996 to 2006, the South African Review Law Commission (SARLC) focused its attention on the drafting of the Child Justice Bill. This Bill culminated in the Child Justice Act, promulgated on 1 April 2010. The Act - the first of its kind in the South African context - was geared specifically towards administering a criminal-justice process for children. The objectives of the Act - as outlined in Chapter One (Section 2(a)) - were protecting the rights of children as provided for in the Constitution (Section 2(b)), and promoting the spirit of ubuntu in the child-justice system (Sections 2(b)) and 2(b)(1)) by fostering the dignity and worth of children and supporting reconciliation by using a restorative justice response (see Section 2 (b)(1)). Ubuntu is an indigenous African concept and refers to a practical humanist disposition towards the world, including compassion, tolerance and fairness (Botha, 2012:148). Botha (2012:148) further states that ubuntu forms an important bridge between communal African traditions and Western traditions, which focus on the individual. What is evident therefore is that the Act clearly mirrors the relevant provisions of the Constitution that are pertinent to children.

A further progressive element introduced by the Act is the issue of assessments of children arrested by police officials for alleged offences. Section 34(2) states that the arrested child is to be handed immediately by the South African Police Services (hereafter the SAPS official), with a written notice, to a probation officer, who would complete an assessment. This assessment would then be used by the court in determining a future placement at a child and youth care centre, prison or back into the parent's custody (see Section 34 (1)). Section 29 describes the placement of a child in a child and youth care centre. The decision on such a placement is undertaken by a presiding officer. The official has to consider a number of salient factors pertaining to the child, when making the decision. Considerations include the age and maturity of the child, the seriousness of the offence, the risk of the child being a danger to themselves or other children, the appropriateness of the level of security at the centre with respect to the seriousness of the offence, and the availability of accommodation at the centre (see Section 29).

Form 5 - a document provided for in the Regulations of the Act - requires that the head of the secure care centre confirm, in writing and under oath, the availability of accommodation. The official must provide reasons as to why the centre can or cannot accept the child awaiting trial. The form also requires the centre manager to reveal the programmes that are in place for children awaiting trial. This information would then be utilised by a presiding officer when considering placement at a centre. This all further illustrates that secure care centres should not merely perform a custodial function, but should have programmes in place that are relevant for awaiting-trial children (see Sections 40(2)(a) and (b)).

Thus, the assessment of the child is a crucial aspect of the process, in that it enables the presiding officer to make an informed decision on appropriate placement. The nature of the assessment in terms of Section 34(1) and (2), as well as an in-depth analysis and 
consideration of all the factors, as detailed in Section 29, ensures that children are appropriately placed as a result of a comprehensive strengths-based assessment.

\section{The Children's Act, 38 of 2005}

This Act focuses on family preservation and the care and protection of children. Chapter Two outlines the general principles (in terms of Section 6). Section 7 highlights that the best interests of children are paramount in all matters concerning their care, protection and wellbeing. It also emphasises that children are to be treated in a fair and equitable manner, ensuring that their dignity is upheld. The Preamble of the Act stipulates that all proceedings, actions or decisions taken in respect of children must be in accordance with children's rights set out in Section 28 of the Constitution - as discussed above.

The Act must be viewed as a comprehensive initiative that attempts to uphold and protect the rights of children. It has extended guidelines on issues pertaining to adoptions, surrogacy and alternative care, and also provides for placement of children in child and youth care centres.

\section{The Children's Amendment Act, 41 of 2007}

The Children's Amendment Act was promulgated because of the inadequacy of the Children's Act in terms of dealing with children. The purpose of the Amendment Act captured in the Preamble (page 2) - is: "To amend the Children's Act, 2005, so as to insert certain definitions; to provide for partial care of children; to provide for early childhood development; to make further provision regarding the protection of children; to provide for prevention and early intervention; to provide for children in alternative care; to provide for foster care; to provide for child and youth care centres and drop-in centres; to create certain new offences relating to children; and to provide for matters connected herewith".

Chapter 13 deals explicitly with the role and functioning of child and youth care centres. In terms of Section 196, secure care centres, including other children's residential facilities such as places of safety, children's homes, reform schools, schools of industries and street-shelters, would be called "child and youth care centres". Terms such as places of safety, children's homes, reform schools and street-shelters are no longer applicable. This change in terminology signifies a transformation in the way children's facilities are perceived and the way they are to operate. Thus there is a move away from labelling towards an approach that is more encompassing of the needs of the child. This directive is innovative, as it emphasises that children's facilities adopt a more a holistic approach towards children in care, as opposed to the running of isolated programmes.

However, a gap has subsequently emerged in practice. Staff at children's facilities that initially provided services to children at children's homes or places of safety are now compelled in terms of the current legislative requirements also to provide services to children awaiting trial (secure care) and children sentenced to reform schools. What is apparent therefore is that as a result of the changes effected by legislation, staff may lack the necessary skill and capacity, and be resistant to working with the different categories 
of children. This may impact negatively on services offered to children at secure care facilities.

Sections 199 and 201 of the Act indicate that programmes are one of the key requirements for the registration of child and youth care centres. Forms 48 and 49 - in terms of the Consolidated Forms as provided in the Regulations under the Children's Act - require that the child and youth care centres outline the types of programmes in place for children, as well programmes in place for the two different genders of children. These sections and prerequisite documents indicate the importance and relevance attached to programmes at the centres. What this in effect means is that should a centre not have the required programmes as stipulated in terms of legislation, it may be prevented from operating as a centre for the admission of children. The importance of programmes at child and youth care centres is confirmed by the fact that children resident at such centres must be meaningfully occupied in constructive programmes and activities, and not left on their own in an unstructured environment.

The Consolidated Regulations, as referred to above, need to be read together with the Children's Act (2005) and Children's Amendment Act (2007). The Regulations serve to qualify or regulate the relevant provisions. These are now discussed.

\section{Consolidated Regulations pertaining to the Children's Act, 2005}

In terms of Section 75(1) of the Regulations of the Children's Act, 2005, the programmes at child and youth care centres must include developmental, therapeutic and recreational aspects. Section 75 (2) of the Regulations provides that:

- there must be a strategy for implementation;

- the programmes must be approved by the provincial head of social development;

- quality assurance of the programmes must be undertaken;

- impact assessment of programmes must be undertaken;

- programmes must be evaluated and reviewed; and

- awareness of the availability of programmes must be raised.

When considering the above six elements, it is clear that the process of implementation of programmes at child and youth care centres is undoubtedly an intense one - requiring a comprehensive implementation strategy. The sentiment embodied in the Act is understandable, as the placement of children at centres is intended to change the behavioural patterns and lives of children who are regarded as being at risk. Programmes are aimed at ensuring that a child's stay at the secure care centre is beneficial and productive, and that the child must be meaningfully occupied. In other words, the youths involved should be empowered in a meaningful way.

The task of designing and implementing quality-approved programmes in line with legislative mandates is an enormous one. It is therefore understandable that the current strategy of the Department of Social Development is to partner with, or outsource the 
implementation of programmes to, civil society organisations or non-governmental organisations (National Department Social Crime Prevention Directorate, 2010).

\section{THE QUALITY AND IMPACT OF PROGRAMMES}

As previously stated, the Regulations of the Children's Act (2005) provide that programmes should meet the developmental, therapeutic and recreational needs of children who are accommodated at child and youth care centres. These programmes are now considered seriatim to determine their quality and impact, and to assess their value on the lives of the children who are resident at such facilities.

\section{Developmental programmes}

Section 75(1)(a) describes the core components of developmental programmes as life skills, independent living for children disengaging from the residential care programme, victim empowerment, family preservation, aftercare, promotion of the rights of children, and income-generating activities. The developmental programmes are clearly focused on teaching or equipping children with life skills, so that they can develop life and social skills, and income-generating initiatives. It seems therefore that the ultimate aim of developmental programmes is to assist children with skills or coping strategies, so that they can lead relatively independent lives.

\section{Therapeutic programmes}

The aim of therapeutic programmes is to bring about behavioural change. This means that the young person is encouraged to change negative thoughts and attitudes to ones that are more positive and manageable, so that positive decisions and behaviour follow. The Department of Social Development (2010) highlights that therapeutic programmes concentrate on cognitive restructuring, behaviour modification, self-awareness and positive self-concept. It is recommended that the content of programmes contain individual and group sessions where the child may reflect or focus on his/her own trauma or developmental areas, the alleged offence, the impact of criminal actions, and a focus on future goals. In addition to therapeutic counselling, children in secure care should also be offered life and social skills and anger management, trauma debriefing, mentorship and life coaching. Section 75(1)(b) of the Regulations describes some of the core components of programmes for meeting the therapeutic needs of children at a child and youth care centre. These are: developmental assessment, psycho-social support, individual counselling, group counselling, trauma counselling, grief counselling, play therapy, family therapy, stress management, conflict resolution, positive communication, positive discipline and behaviour change.

The Department of Social Development (2010) also emphasises the importance of Care Plans and Individual Developmental Plans (IDPs). These IDPs must be drawn up for children placed in child and youth care centres. The Care Plan is a long-term permanency plan for the child, which spans three to five years. It is a prerequisite for the admission of a child to a centre and is compiled by the multidisciplinary team at the centre, together with the child and significant others such as parents, guardians and teachers. One of the objectives of assessment is "to understand the child, as well as the 
immediate and medium-term developmental issues and to take appropriate actions and/or provide and facilitate appropriate programme resources based on an IDP" (Department of Social Development, 2010). The relevance of developmental assessment is the backdrop of the therapeutic programme for children residing at care centres. The importance of the IDP is that it includes therapeutic, developmental and recreational aspects in one plan. The aim of the IDP is to focus on the child individually and address his/her individual needs. This individual focus reflects the transformative nature of the new legislation.

\section{Recreational programmes}

Section 75(1)(c) in the Regulations outlines the core components of recreational programmes as sport, art, drama, dancing, singing and board games. It seems that the aim of recreational programmes is to promote rest, relaxation and creativity amongst children. In line with recreational programmes, vocational programmes should also be offered to children in a secure care setting, and should be in line with sustainable development and the economic empowerment framework. Examples of vocational programmes are gardening/food-gardens, bricklaying, carpentry and woodwork, motor mechanics, electrical repairs, horticulture, beauty and hairdressing. The relevance of such programmes to children who find themselves in child and youth care centres is that these skills are portable. Thus children would be able to learn and utilise the skill once they are released - for securing employment and/or for income-generation initiatives.

In examining the core components of programmes, what emerges is that they are undoubtedly intended to be beneficial to the child. Their objectives are to empower the child to become equipped with relevant skills to enable him/her towards a path of independent living and productive adulthood. The intention of such programmes is also aimed at obviating possible recidivism. However, it is premature at this stage to comment on the effectiveness of these programmes, as the programme design in terms of the core components articulated above has only recently been implemented (Department of Social Development, 2011a,b,c). To date no evaluation studies have been documented in terms of implementation of the types of programmes identified above. According to the Department of Social Development (2011a,b,c), the success of programmes will be measured through an evaluation of their implementation.

\section{CURRENT SITUATIONAL ANALYSIS OF PROGRAMMES IN SECURE CARE CENTRES}

The Four Chakras, who were private consultants commissioned by the Department of Social Development in 2009, completed a situational analysis of secure care centres in South Africa. It was reported that "there was little evidence of programmes that contributed to the empowerment and improvement of social functioning of children awaiting trial. Neither was there evidence of an integrated approach to the programmes being offered" (Department of Social Development, 2010).

The issue of the development and implementation of programmes for secure care centres prompted the National Department of Social Development (NDSD), under the Social 
Crime Prevention Directorate, to make a concerted attempt to address the issue of programmes for children in conflict with the law, as mandated by current children's legislation. The National Department Social Crime Prevention Directorate identified the glaring lacunae that exist as staff shortages, lack of documented programmes designed by the Department of Social Development, a lack of accreditation and standardisation of programmes, and a lack of programmes in rural communities (National Department Social Crime Prevention Directorate, 2010). The emphasis of the Directorate was that, if adequate effort was put into programme design, this would impact positively on service delivery (National Department Social Crime Prevention Directorate, 2010).

The National Department Social Crime Prevention Directorate coordinated a series of national workshops in August and November 2010 and August 2011 - in conjunction with their stakeholders - to address the issue of standardised programmes in secure care settings. The following programmes were identified and developed because of their perceived importance, relevance and the particular benefits they provide children: sexual offences, substance abuse, life skills, after care, and restorative justice. The life skills and substance abuse programmes were termed "Rhythm of Life" and "Wake Up Call" respectively. The Wake Up Call, Rhythm of Life and Sexual Offences programmes were rolled out and implemented in KwaZulu-Natal in 2012 (Rhythm of Life Manual, 2011a; Sexual Offences Manual, 2011b; Wake Up Call Manual, 2011c).

Bosasa is a private company that provides for privately-run secure care centres and is nationally based. The organisation has secure care centres in several provinces, namely Gauteng, Western Cape, Eastern Cape, Northern Cape, North-West and Limpopo. The organisation posits that they have programmes in place that are aligned to norms and standards, in terms of legislative requirements, and have been accredited by the Department of Social Development (Bosasa Programmes Manual, 2010). Some of the programmes that they offer to children awaiting trial include educational awareness programmes, vocational programmes and therapeutic programmes. In terms of vocational programmes, Bosasa offers furniture making, upholstery, bricklaying, plumbing, arc welding, sewing, catering, arts and crafts, Adult Basic Education Training (ABET) and computer literacy (Bosasa Programmes Manual, 2010).

\section{RECOMMENDATIONS}

It is submitted that, while the legislative mandates are commendable in terms of their objectives to assist and safeguard the best interest of children, there are certain elements that can be seen as stumbling blocks in terms of their effectiveness and implementation. These include the slow or staggered process of implementation, which can be attributed to manpower challenges and inadequate funding. The cost of building and implementing a fully functional secure care centre from scratch in terms of the blueprint for secure care centres in South Africa is estimated at R35 855784.00 with the cost per person being estimated at R600 000.00 (Department of Social Development, 2010). The authors' submit that these costs are exorbitant and it is questionable whether the National Treasury would be willing to release such funds. 
As has been alluded to, therapeutic programmes should form the basis of all other types of programmes offered to a child at a secure care centre, despite the fact that secure care is a short-term placement. Recreational and developmental programmes are relevant and should be part of the "curriculum" at secure care centres. However, they should be included as part of the therapeutic programme, in the form of the child's IDP - which has already been discussed.

The content of therapeutic programmes - which includes assessment, interviewing and counselling - is crucial and can also be used to assess whether a child awaiting trial at a secure care centre is also in need of care in terms of the Children's Act, 2005. It is submitted that children who commit crimes are also in need of care and protection, and that the act of committing a crime is an indication that the child "is in trouble" and requires help for a whole variety of reasons. The young person thus requires guidance and support.

In order to enhance and promote the importance of the therapeutic nature of programmes at secure care centres, the staff establishments of such facilities should include a multidisciplinary team comprising social workers, child-care workers and nurses, a psychologist, occupational therapist and/or a visiting doctor or psychiatrist. These roleplayers are highly relevant in inculcating and enhancing the therapeutic milieu at a child and youth care centre. The Department of Social Development (2010) states that staff must be selected for their positive attitude and willingness to work with troubled children, and that there should be staff development or in-service training programmes in place for staff working with such children. Such staff development for personnel working directly with offenders is regarded as being absolutely essential, particularly for staff working at secure care centres.

Working with children who commit crimes is intense work, which may impact on the coping capacity of staff members. Therefore, programmes such as structured staff training, employee wellness and on-line and structured supervision of staff must be in place. The authors' agree with Reyneke and Reyneke (2010) about the challenges experienced by those who work with children in conflict with the law, and that assisting them to cope with their problems is crucial. Such workers should receive supervision of the highest quality. The international legal instrument - the United Nations Rules for the Protection of Juveniles Deprived of their Liberty (JDL, 1990) - concurs with this, stating that only trained staff with high levels of professionalism should work with children who are arrested. The authors are in agreement with this assertion and recommend that the qualifications of staff also need to be taken into consideration when employing staff at secure care centres. Furthermore, what is also essential is that staff need to know what is expected of them. These are outlined in job contracts, job descriptions and performance agreements that staff sign with employers. Staff need to have a sense of understanding of their work from the outset. Working with troubled children and especially children awaiting trial is both stressful and demanding. Occurrences of violence, assault, bullying, sexually deviant behaviour and gangster-type activities are common. Staff need to be committed and trained to alleviate such incidences. 
The transformation of the child and youth care system needs a developmental, strengthsbased, ecological approach to be in place at residential settings for children (InterMinisterial Committee on Young People at Risk, 1996a). The Minimum Standards document (Inter-Ministerial Committee on Young People at Risk, 1998) outlined a series of 15 practice principles and 21 minimum standards required to be in place to bring about a child-friendly and therapeutic milieu when working with children residing at a children's residential facility. Some of the minimum standards are engagement, safety, therapeutic programmes, developmental opportunities and programmes, social and emotional care, and IDPS and Care Plans. The importance of such standards is that they have also become legislated as norms and standards in respect of the functioning of child and youth care centres (Consolidated Regulations Pertaining to the Children's Act 2005). The Department of Social Development (2010) also outlines various norms and standards that are required for the functioning of secure centres. The value that the norms and standards provide is that they emphasise key focus areas such as programmes and other relevant activities that are compulsory minimal requirements that need to be in place when working with children. The inference is that should a child and youth care centre not comply with the prescribed norms and standards, it is providing an inadequate service.

One of the ways to ensure that quality programmes are sustained, especially at children's facilities, is through a process of quality assurance. Reference to the quality assurance is made in the regulations of the Children's Act (2005), which not only requires that child and youth care centres undergo a quality assurance process, but that it is also undertaken by an independent quality assurance team. Quality assurance is an exercise whereby the norms and standards required to be in place at a child and youth care centres - one being programmes - are reviewed regularly in terms of their implementation, ensuring "that such standards remain relevant and appropriate" (Inter-Ministerial Committee on Young People at Risk, 1996a:98).

Another way in which programmes may reflect their authenticity and ensure their longevity is through the accreditation process as stipulated in the Child Justice Act (2008). In making reference to diversion programmes, the accreditation process is highlighted in terms of Section 56 of the Child Justice Act of 2008. Some of the key elements in respect to the accreditation process are a policy framework for accreditation, a system for the maintenance of accreditation, criteria for the evaluation of the content of programmes, monitoring of programmes, and issuing of certificates of accreditation by the Cabinet Minister (see Section 56 of the Child Justice Act).

Monitoring and evaluation of programmes are also essential. The implementation of programmes can be monitored through regular, monthly or quarterly reporting on programmes in respect of which feedback is provided as well as the evaluation of programmes through formatted evaluation templates.

It is submitted that implementing the above strategies would ensure the sustainability of quality programmes at secure care facilities. This process of monitoring is significant in ascertaining the effectiveness of the programmes that are proposed by legislation. It is 
also aimed at ensuring that children derive the optimal benefit from these programmes during their stay at secure care facilities.

\section{CONCLUSION}

What can be gleaned from an examination of the status of current legislation such as the Probation Services Act, Children's Act and its Regulations, the Children's Amendment Act, and the Child Justice Act is that they have the issue of programmes and their implementation as their core focus. These programmes must add value to a child's life and steer him/her away from a criminal, anti-social life style, and prevent a child from re-offending. Furthermore, such programmes must be of an acceptable standard, accredited and approved before they are put into place.

In order to implement the programmes effectively and to ensure that the programmes are sustained, staff who implement them also need to be supported and capacitated. Staff need to be trained and supported, and the necessary resources need to be made available for staff to implement the programmes. Training and in-service/in-house training are crucial as staff need to be upgraded on a regular basis. Failure to implement training programmes will lead to legislation becoming redundant, and the desired effect of assisting troubled children will become null and void.

In reviewing the legislation governing secure care centres, it is clear that programmes that are therapeutic in nature should be the basis of all programmes that are available to children awaiting trial. Without a focus on therapeutic content, the rehabilitation or change which is regarded as being core function or purpose of the programmes, as discussed above, will not materialise for young people in trouble with the law.

\section{REFERENCES}

BADENHORST, C. 2012. Child Justice Alliances, $2^{\text {nd }}$ Year Implementation Report on Child Justice Act. [Online] Available: http://www.childjustice.org.za/publications/ BadenhorstCJAImplenatation2_2012.pdf. [Accessed: 03/03/2013].

BEUKES, K. \& GANNON, B. 1996. An orientation to child \& youth care $\left(2^{\text {nd }}\right.$ ed). Claremont: National Association of Child Care Workers.

BOSASA. 2010. Programmes Manual Bosasa YDC and the Child Justice Act. Gauteng: Design House.

BOTHA, C. 2012. Statutory Interpretation. An introduction for students $\left(5^{\text {th }} \mathrm{ed}\right)$. Cape Town: Juta \& Co Ltd.

CHILD JUSTICE PROJECT. Undated. Interim National Protocol for the Management of Children Awaiting Trial Document. Pretoria: Government Printers. CHILD JUSTICE PROJECT. 2002. A Situational Analysis of Reform Schools and Schools of Industry in South Africa. [Online] Available: http://www.pmg.org.za/docs/ 2003/appendices/030228situation.htm. [Accessed: 20/09/2013].

CHILDREN'S ACT, 38 of 2005. Pretoria: Government Printers.

CHILDREN'S AMENDMENT ACT, 41 of 2007. Pretoria: Government Printers. 
CHILD JUSTICE ACT, 75 of 2008. Pretoria: Government Printers.

CONSOLIDATED REGULATIONS PERTAINING TO THE CHILDREN'S ACT, 38 of 2005. Pretoria: Government Printers.

CONSTITUTION OF THE REPUBLIC OF SOUTH AFRICA, ACT 108 of 1996. Pretoria: Government Printers.

CORRECTIONAL SERVICES ACT, 8 of 1959. Pretoria: Government Printers.

CORRECTIONAL SERVICES AMENDMENT ACT, 17 of 1994. Pretoria: Government Printers.

CURRIE, I. \& DE WAAL, J. 2005. The Bill of Rights Handbook ( $5^{\text {th }}$ ed). Claremont: Juta \& Company.

DEPARTMENT OF SOCIAL DEVELOPMENT. 2010. Blueprint, Minimum Norms and Standards for Secure Care Facilities in South Africa. Pretoria: Government Printers.

DEPARTMENT OF SOCIAL DEVELOPMENT. Undated. Guidelines for Probation Officers, Assistant Probation Officers and Child and Youth Care Workers to Provide Appropriate Services to Children in Conflict with the Law. Pretoria: Government Printers.

DEPARTMENT OF SOCIAL DEVELOPMENT. 2011a. Rhythm of Life Manual. Pretoria: Government Printers.

DEPARTMENT OF SOCIAL DEVELOPMENT. 2011b. Sexual Offences Manual. Pretoria: Government Printers.

DEPARTMENT OF SOCIAL DEVELOPMENT. 2011c. Wake Up Call Manual. Pretoria: Government Printers.

DEVENISH, G.E. 1999. A commentary on the South African Bill of Rights. Durban: Butterworths Publishers (Pty) Ltd.

FINE, N. 1996. Transforming institutional thinking through the walls. UWC: Community Law Centre.

INTER-MINISTERIAL COMMITTEE ON YOUNG PEOPLE AT RISK. $1996 \mathrm{a}$. Interim Policy Recommendations. Pretoria: Government Printers.

INTER-MINISTERIAL COMMITTEE ON YOUNG PEOPLE AT RISK. 1996b. In whose best interest? Report on Places of Safety, Schools of Industry \& Reform Schools. Pretoria: Government Printers.

INTER-MINISTERIAL COMMITTEE ON YOUNG PEOPLE AT RISK. 1998. Minimum Standards: South African Child and Youth Care System. Pretoria: IMC.

KWAZULU-NATAL DEPARTMENT OF SOCIAL DEVELOPMENT. 2012. Annual Performance Plan 2012-2013. KwaZulu-Natal: CPW Printers. 
NATIONAL DEPARTMENT SOCIAL CRIME PREVENTION DIRECTORATE, DEPARTMENT OF SOCIAL DEVELOPMENT. 2010. Hand-out. Pretoria: National Department Social Crime Prevention Directorate.

PROBATION SERVICES ACT, 116 (amended). 1991. Pretoria: Government Printers.

REYNEKE, R. \& REYNEKE, M. 2010. Evaluating the application of restorative justice at the Mangaung One-stop Child Justice Centre. Social Work/Maatskaplike Werk, 46(3):358-380.

SKELTON, A. 2004. The influence of the theory and practice of Restorative Justice in South Africa with special reference to Child Justice. Pretoria: Faculty of Law, University of Pretoria. (Doctoral Thesis)

SLOTH-NIELSEN, J. \& DE VILLIERS, S. 1998. Children in prison in South Africa: a situational analysis. University of Western Cape: Community Law Centre.

VILJOEN, F. 2009. The African Charter on the Rights and Welfare of the Child. In: BOEZAART, T. (ed) Child Law in South Africa. Claremont: Juta \& Co Ltd.

UNITED NATIONS GENERAL ASSEMBLY. 1990. The United Nations Rules for the Protection of Juveniles Deprived of their Liberty. New York City: United Nations.

Ms Annie Singh, School of Law, University of KwaZulu-Natal; Ms Vanessa Singh, Social Worker, Department of Social Development, University of KwaZulu-Natal, Durban, South Africa. 